\title{
THE EFFECT OF SHUTTLE RUN AND ZIG ZAG RUN EXERCISES AND CONFIDENCE ON PASSING PRODUCTIVITY ON TANJUNGBALAI FC PUMATA FUTSAL PLAYERS
}

\author{
*Muhammad Amin Syahputra, Sanusi Hasibuan, Novita \\ Correspondence: Fakultas Ilmu Keolahragaan, Universitas Negeri Medan, Medan, \\ Indonesia \\ E-mail: muhammad.aminsyahputra16@gmail.com
}

\begin{abstract}
The focus of this study aims to determine the effect of shuttle run, and zig-zag run training and self-confidence on passing productivity in Futsal players Pumata FC Tanjungbalai trying to improve athlete achievement among teenagers. This study uses an experimental research method by level $2 \times 2$, so the hypothesis submission is carried out using a two-way analysis of variance (ANAVA). After that, hypothesis testing was carried out using a two-way analysis of variance (ANAVA). This research was carried out at the PUMATA FC Team's training ground which was located at the Tanjungbalai city futsal field. The implementation time is about four weeks, with meetings three times a week. The sample of this research is all Pumata FC players consisting of 20 people who are given shuttle run training and zig-zag run training. Based on the analysis results above, it shows that there are differences in mean in the four groups by giving shuttle run and zig-zag run exercises. The highest mean value was obtained in the high self-confidence group trained with the zig-zag run, which was 8.60 (if rounded up to 9 successful passes). Meanwhile, the Towest mean value was obtained in the low selfconfidence group trained with the shuttle run, which was 6.20 (if rounded up to 6 successful passes) Physical Education. Health and Recreation
\end{abstract}

Keywords: Confidence, Passing,Shuttle Run, Zig Zag Run

\section{Introduction}

Advances Futsal is a sport that is very well known and favored by almost all levels of Indonesian society, both in the city and in the village, from children to the elderly. However, the game of futsal is mostly played by teenagers to adults. This is proven by the number of futsal clubs in each region and futsal matches that are held locally, regionally, nationally, and internationally. The current trend of futsal is developing so fast that everyone is so enthusiastic about one of these sports, and global information plays an important role in all aspects, including finding information about tournament matches, up-to-date news about tournaments, tournament matches schedules.

According to Lhaksana in Abdul Narlan, et al (2017:241), Futsal in Spanish is "futbol sala," which means indoor football. The game of futsal is the same as

PJKR 
football. What distinguishes these two games is the number of players, the size of the ball, the size of the field, and there are some basic techniques that are also different. One of the advantages of playing futsal is that it has a small field size, so it does not require a very large area like a football field.

In the world, there are two international futsal bodies, namely AMF (Association Mundial de Futsal) with POFI (Indonesian Futsal Sports Association) as its representative in Indonesia and FIFA, which oversees football (men and women), futsal, beach football with PSSI as its representative in Indonesia. Futsal players must learn to play accurately in basic techniques, such as passing, control, dribbling, and shooting. To master these basic techniques, players must first master individual techniques, including speed, agility, and coordination. There are often violations that are not seen by the referees who are on the field. The basic game of futsal is not much different or even almost the same as its predecessor sports or football (football), such as passing, dribbling, control, heading, shooting. Dribbling is kicking the ball intermittently or slowly. Dribbling aims to approach the distance to the target, pass the opponent and hinder the game, the foot used in dribbling is the same as the foot used for kicking the ball. Players who are serious about practicing skills in mastering futsal techniques will be able to master futsal techniques better than players who do not take training patterns seriously.

This basic technique is called passing. In futsal and football games, passing is generally done using the inside of the foot. In addition, passing is also done using the outside of the foot, heel, and toe. Meanwhile, according to Sahda Halim, good passing will make it easier for your friends to receive the ball. The purpose of passing the ball is to roll the ball as well as possible and measure it so that it is easier for colleagues/friends to receive it properly. Physical imperfections in certain people so that it becomes a form of deficiency or disability. The emergence of disability can be motivated by health problems that arise from birth, chronic diseases and equipment, and injuries that can be caused by accidents, wars, riots, disasters, and so on.-Disability is closely related to health, both physically and mentally. Many disabilities are motivated by health problems, and vice versa.

According to Muhammad Nur (2015: 24), exercise is a process of systematically preparing physically and mentally for children to achieve optimal performance quality by being given a regular, directed, increasing, and repeated training load. In stages and systematically, which is done not only once or twice but repeatedly. The repetition is carried out by considering the gradual increase in the load to the optimal point. According to Syarif Hidayat (2014: 61), agility is a person's ability to be able to change direction quickly and precisely when moving without losing balance. Agility is closely related to speed and flexibility. Without the elements of both good, one cannot move swiftly. In addition, the balance factor is very influential on a person's agility ability. Forms of agility training can be done in the form of a shuttle run, a zig-zag run, a standing squat (squat thrust), and others. According to Sejahtera (2010: 80), Shuttle Run is an exercise where 
every time he comes to a point, he has tried to quickly turn around to run to the starting point and is done repeatedly as the desired target. Straight. Athletes run back and forth as quickly as possible from one point to another ten times. Each time he came to a point, he had to try to turn around to run towards another quickly. According to Sejahtera (2010: 80), a zig-zag run is a form of exercise that is carried out with winding movements through the signs that have been prepared, with the aim of practicing the ability to change direction quickly.

According to Pradipta Sarastika in Endah Rahayuningdyah (2016; 2), selfconfidence can be interpreted as a belief in one's own abilities that are adequate and realize that one's abilities can be utilized appropriately. According to Lauster in Siska, et al (2003:69), self-confidence is not a trait that is inherited (innate) but is obtained from life experience and can be taught and instilled through education, so that certain efforts can be made to form and increase self-confidence.

In this case, after being observed during the match, it was seen that some of the reasons for the PUMATA Team were still low in the number of passes by players during the match because there were still many passes to the opponent or wrong passes, and it took too long for players to make the decision to pass. The thing that most often results in a small number of passes is the absence of teammates who make movements and create positions/spaces to be able to pass passes to friends. In this case, the process of moving to change positions as quickly as possible.

In this case, it can be seen that agility in moving is the goal of research which will be able to create a greater number of passes.

As for what the players experienced when competing, it was seen that the players were seen playing individually or playing alone. Then they played without the direction given to the players. And decreased confidence in being able to beat the opposing team that will be faced. And feel afraid when you make a mistake. Fear of being played against a better team. On the other hand, some players act too enthusiastically to cause mistakes that should not be made. In this case, the psychological factor about self-confidence that I will discuss in this research.

Based on the description of the information above, it is necessary to conduct research discussing the Effect of Shuttle Run and Zig Zag Run Exercises and Confidence on Passing Productivity in Pumata FC Tanjungbalai Futsal Players.

Research design is the method used to collect research data so that research results can be proven. The research design used in this study is the treatment by level $2 \times 2$ design, where each independent variable is classified into 2 (two). The independent variables of treatment were classified into two forms of treatment (A), namely treatment with Shuttle run (A1) and Zig-zag run (A2) exercises. At the same time, the independent moderator variables are classified into two levels of self-confidence (B), namely high confidence (B1) and low confidence (B2). The Design Treatment by level $2 \times 2$ design can be explained as shown in the following table. 


\begin{tabular}{|l|c|c|}
\hline Self-confident (B) & Exercise Shuttle run (run & Zig-zag run exercise $\left(\mathrm{A}_{2}\right)$ \\
\hline High Confidence $\left(\mathrm{B}_{1}\right)$ & $\mathrm{A}_{1} \mathrm{~B}_{1}$ & \\
\hline Low Confidence $\left(\mathrm{B}_{2}\right)$ & $\mathrm{A}_{1} \mathrm{~B}_{2}$ & $\mathrm{~A}_{2} \mathrm{~B}_{1}$ \\
\hline
\end{tabular}

Data collection techniques are tools used by data collectors or carrying out the task of collecting data that is being studied. In accordance with the research design, there are two kinds of data that must be collected, namely: (1) data on the results of passing productivity and (2) data on the confidence of Pumata FC players.

\section{Conclusion}

Based on the results, it can be seen that the shuttle run and zig-zag run exercises provide a better change, namely an increase in the number of passing productivity compared to before the shuttle run and zig-zag run exercises were given. The coach is the decider for the players or for the team. The coach should be able to provide the type of exercise that is appropriate to the conditions of the players, and the type of exercise being trained can increase the productivity of the player's passing. The coach must also be able to instill confidence in the players so that they are not easily down when competing with stronger opponents.

\section{References}

Akhmad, Imran. 2013. Dasar-Dasar, Melatih Fisik Olahragawan. Medan: Unimed Press

Ameldi, Roni, dkk. 2018. Sistem informasi reservasi lapangan futsal berbasis android pada lapangan futsal. Jurnal ilmiah rekayasa dan manajemen sistem informasi, 4(1): 82.

Arikunto, Suharsimi, 2010. Prosedur Penelitian Suatu Pendekatan Praktik. Jakarta: Rineka Cipta

Aristiani, Rina. 2016. Meningkatkan Percaya Diri Bahwa Melalui Layanan Informasi Berbantuan Audiovisual. Jurnal Kusding GUSJIGANG. 2(2): 185

Bompa \& Carrera, 2005. Periodization Training For Sport 2n. USA: Versa Press

Bompa. 2012. Theory And Methodology Of Training The Key To Athletic Performa, Third Edition. Canada: Kendall/Hurt Publishing

Bompa \& Buzzichelli. 1999. Periodization Training For Sports, Third Edition. USA: Human Kinetics

PJKR_

https://jurnal.unimed.ac.id/2012/index.php/jpehr 
Brewer, W. Britton. 2009. Sport Psychology. USA: WILEY-BLACKWELL

Cissik \& Barnes. 2011. Sport Speed And Agility Training, Second Edition. USA: ZUMA Press

Hatmisari, Dwi. Dkk. 2007. Pelatihan Pelatih Fisik Level 1. Jakarta: Asdep Pengembangan Tenaga Dan Pembinaan Keolahragaan, Kementrian Negara Pemuda Dan Olahraga

Effendi, Hastria. 2016. Peranan Psikologi Olahraga Dalam Meningkatkan Prestasi Atlet. Jurnal Ilmu Pengetahuan Sosial. (1): 26

Fauziah, H. 2011. Pengaruh Latihan Pliometrik terhadap Peningkatan Vertical Jump pada Atlet Basket Putra Usia Dini. Makassar: Program Studi Fisioterapi Fakultas Kedokteran Universitas Hasanuddin.

Firdaus, Kamal. 2012. Psikologi Olahraga Teori Dan Aplikasi. Padang: FIK UNP Presss

Hariadi, A.M. 2017. Handal tentang futsal. Surabaya: jepe press media utama

Harsono, 2018. Latihan Kondisi Fisik. Bandung: PT. Remaja Rosdakarya

HB, Bafirman. 2013. Kontribusi-Fisiologi Olahraga Mengatasi Resiko Menuju Prestasi Optimal. Jurnal Media Ilmu Keolahragaan Indonesia. 3(1): 40

Hermans \& Engler. 2009. Futsal Technique, Tacties, Training. USA: Sport Publisher'Association (WSPA)

Hidayat, Syarif. 2014. Pelatihan Olahraga Teori Dan Metodologi. Yogyakarta: Graha Ilmu

Husdarta. 2014. Psikologi Olahraga. Bandung: Alfabeta

Kadek \& Chandra. 2014. Pembentukan Dan Pembinaan Kondisi Fisik. Yogyakarta: Graha Ilmu

Kerru, Alamsyah, dkk. 2015. Pengaruh Latihan Shuttle Run Dan Lari Zig-Zag Terhadap Keterampilan Dribbling Dalam Permainan Bola Basket Pada Siswa SMP Negeri 1 Biromaru. E-journal Tadulako Physical Education, Health And Recreation. 3(12): 2-3

Kurniawan, Febi. 2017. Efektivitas model latihan passing control Febi futsal games terhadap peningkatan hasil passing control olahraga futsal untuk pemain pemula. Motion, 8(2): 214

Komarudin. 2018. Life Kinetik Dan Performa Psikologis. Bandung: Rosdakarya

Lhaksana, J. 2011.Taktik dan Strategi Futsal Modren. Jakarta: Be Champion

Narlan, Abdul, dkk. 2017. Pengembangan instrumen keterampilan olahraga futsal. Jurnal Siliwangi, 3(2): 241.

Narti, Aulia, R. 2009. Futsal. Bandung: Indah jaya adipratama

Nolvin. 2013. Meningkatkan Kecepatan Lari Sprint Melalu Permainan Olahraga Tradisional Benteng Hadang Pada Siswa Kelas V Sd Inpres 2 Kamarora Kecamatan Nokilalaki Kabupaten Sigi. Jurnal Olah Raga.Pendidikan Jasmani, Kesehatan Dan Rekreasi FKIP Universitas Tadulako Kampus Bumu Tadulako Tondo Palu Sulawesi Tengah.

Noviada, Gede, dkk. 2014. Metode pelatihan taktis passing berpasangan statis dan passing sambil bergerak terhadap keterampilan teknik dasar passing

PJKR_

https://jurnal.unimed.ac.id/2012/index.php/jpehr 
control bola futsal. E-Journal pko universitas pendidikan ganesha jurusan pendidikan pelatihan olahraga, 1: 3

Majid, Hariadi, Abdul. 2014. Handal Tentang Futsal. Surabaya: JP Book

Murhananto, 2008. Dasar-dasar Permainan Futsal.

Mylsidayu, Apta. 2014. Psikologi Olahraga. Jakarta: Bumi Aksara

Pratama, I R. Nasuka, dan Hadi, (2015). Pengaruh Latihan Plyometrics Terhadap Peningkatan Kecepatan, Kelincahan Dan VO2MAX. Skripsi Universitas Negeri Semarang, Indonesia.

Rahayuningdyah, Endah. 2016. Upaya Meningkatkan Percaya Diri Melalui Layanan Konseling Kelompok Pada Siswa Kelas VIII D Di SMP Negeri 3 Ngrambe. 1(2): 2

Roesdiyanto \& Budiwanto, Setyo. 2008. Dasar-Dasar Kepelatihan Olahraga. Malang: Laboratorium Ilmu Keolahragaan UNIVERSITAS NEGERI MALANG

Sajoto, Mochamad. 1988. Pembinaan Kondisi Fisik Dalam Olahraga. Jakarta: FPOK-IKIP Semarang

Sejahtera. 2010. Perbedaan Pengaruh Latihan Zig-Zag Drill Dan Latihan Shuttle Run Terhadap Kelincahan Dan Keterampilan Dribbling Dalam Permainan Bola Basket Siswa Putra SMA Advent Air Bersih Medan. Jurnal Ilmu Keolahragaan. 8(1): 80

Shaw, et al. 2005. Instant Notes Sport And Exercise Psychology. USA: BIOS Scientific Publisher

Siska, dkk. 2003. Kepercayaan Diri Dan Kecemasan Komunikasi Interpersonal Pada Mahasiswa. Junal Psikologi, (2): 69

Suharjana \& Gilang. 2010. Profil Kebugaran Awal Member Baru Pria Usia 20-25 Di Finess Center Gedung Olahraga FIK-UNY. Jurnal Ilmiah Kesehatan Olahraga. 4(1): 81

Sukirno. 2010. Belajar Bermain Futsal. Bogor: Arya Duta

Sudjana. 2005. Metode Statistika. Bandung: Tarsito

Sukadiyanto. 2005. Pengantar Teori dan Metodologi Melatih Fisik. Yogyakarta: Fakultas Ilmu Keolahragaan Universitas Negeri Yogyakarta.

Udam, Melkianus. 2017. Pengaruh Latihan Shuttle Run Dan Zig Zag Terhadap Kemampuan Dribbling Bola Pada Siswa Sekolah Sepakbola (SSB) Imanuel Usia 13-15 Di Kabupaten Jayapura. Jurnal Pendidikan Jasmani Olahraga Dan Kesehatan. 3(1): 61

Wiguna, Ida, Bagus. 2017. Teori dan Aplikasi Latihan Kondisi Fisik. Depok: Rajawali Press

Wibowo, Satrio \& Rahayu, Nur. 2016. Pengaruh latihan Mental Imagery Terhadap Hasil Tembakan Atlet Menembak Rifle Jawa Barat. Jurnal Terapan Ilmu Keolahragaan. 1(2): 24

Yahya, S., dkk. 2014. Perbandingan Latihan Zig-Zag dan Dodging Run terhadap Keterampilan Menggiring Bola pada Permainan Sepakbola Siswa Kelas XD Sma Negeri Sumuwa (Skripsi). Gorontalo: Fakultas Ilmu-Ilmu dan Keolahragaan Universitas Negeri Gororntalo.

PJKR

https://jurnal.unimed.ac.id/2012/index.php/jpehr 